
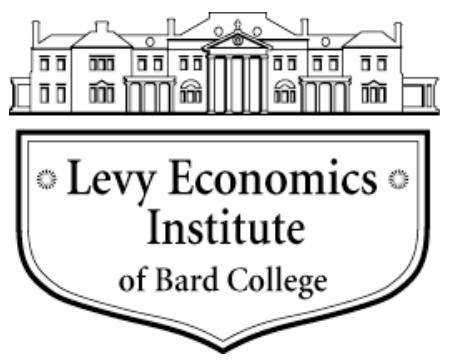

Working Paper No. 878

\title{
The Short- and Long-run Inconsistency of the Expansionary Austerity Theory: A Post-Keynesian/Evolutionist Critique
}

by

\author{
Alberto Botta* \\ University of Greenwich
}

December 2016

\begin{abstract}
* Department of International Business and Economics, Greenwich Political Economy Research Centre, University of Greenwich. Email: A.Botta@greenwich.ac.uk.
\end{abstract}

The Levy Economics Institute Working Paper Collection presents research in progress by Levy Institute scholars and conference participants. The purpose of the series is to disseminate ideas to and elicit comments from academics and professionals.

Levy Economics Institute of Bard College, founded in 1986, is a nonprofit, nonpartisan, independently funded research organization devoted to public service. Through scholarship and economic research it generates viable, effective public policy responses to important economic problems that profoundly affect the quality of life in the United States and abroad.

Levy Economics Institute

$$
\text { P.O. Box } 5000
$$

Annandale-on-Hudson, NY 12504-5000

http://www.levyinstitute.org

Copyright (C Levy Economics Institute 2016 All rights reserved 


\section{ABSTRACT}

This paper provides a critical analysis of expansionary austerity theory (EAT). The focus is on the theoretical weaknesses of EAT - the extreme circumstances and fragile assumptions under which expansionary consolidations might actually take place. The paper presents a simple theoretical model that takes inspiration from both the post-Keynesian and evolutionary/institutionalist traditions. First, it demonstrates that well-designed austerity measures hardly trigger short-run economic expansions in the context of expected longlasting consolidation plans (i.e., when adjustment plans deal with remarkably high debt-toGDP ratios), when the so-called "financial channel" is not operative (i.e., in the context of monetarily sovereign economies), or when the degree of export responsiveness to internal devaluation is low. Even in the context of non-monetarily sovereign countries (e.g., members of the eurozone), austerity's effectiveness crucially depends on its highly disputable capacity to immediately stabilize fiscal variables.

The paper then analyzes some possible long-run economic dynamics, emphasizing the high degree of instability that characterizes austerity-based adjustments plans. Path-dependency and cumulativeness make the short-run impulse effects of fiscal consolidation of paramount importance to (hopefully) obtaining any appreciable medium-to-long-run benefit. Should these effects be contractionary at the onset, the short-run costs of austerity measures can breed an endless spiral of recession and ballooning debt in the long run. If so, in the case of nonmonetarily sovereign countries debt forgiveness may emerge as the ultimate solution to restore economic soundness. Alternatively, institutional innovations like those adopted since mid-2012 by the European Central Bank are required to stabilize the economy, even though they are unlikely to restore rapid growth in the absence of more active fiscal stimuli.

Keywords: Fiscal Policy; Expansionary Austerity Theory; Post-Keynesian Macro Models

JEL Classifications: E12, E61, E62 


\section{THE THEORY OF EXPANSIONARY AUSTERITY (EAT) AND ITS CRITIQUES: AN OVERVIEW}

Expansionary austerity theory (EAT) is part of a long-standing debate in economic literature on the effectiveness of fiscal policy. Nonetheless, EAT as we currently know it emerged at the beginning of the 1990s when some economists started to argue that discretionary expansionary fiscal policies may have non-Keynesian effects (see Giavazzi and Pagano [1990 and 1996]; Alesina and Perotti [1995]; more recently, see Alesina and Ardagna [2010 and 2012]). According to them, at least under certain circumstances, ${ }^{1}$ expansionary fiscal policies may be ineffective for stimulating economic activity, and, by giving rise to unsustainable fiscal stances, may actually put at risk the solidity of the financial system. Symmetrically, well-conceived fiscal restrictions may stimulate private consumption and investment, as well as improve export dynamics. Eventually, economic activity may expand rather than contract, and give rise to a case of expansionary fiscal consolidation.

The vast majority of the existing critiques of EAT have addressed the shortcomings of the econometric techniques adopted by EAT supporters in order to empirically validate their theoretical propositions. The first strand of criticisms points to the concept of (changes in the) cyclically adjusted primary balance (CAPB) as an erroneous and misleading measure of discretionary fiscal policy shocks (see Guajardo, Leigh, and Pescatori 2011; Baker and Rosnick 2014). A second critique raises the issue of an inverse causality between economic dynamics and fiscal policy, since different phases of the business cycle may have relevant implications as to the restrictive/expansionary fiscal stances governmental authorities may eventually adopt (Baker and Rosnick 2014). Finally, a growing body of empirical analyses provides evidence of a cyclecontingent fiscal multiplier, which is largely positive during recessions (Guajardo, Leigh, and Pescatori 2011; Auerbach and Gorodnichenko 2012; Qazizada and Stockhammer 2015). It is easy to see how this evidence is radically at odds with the concept of a negative fiscal multiplier implicitly advocated by EAT.

The aim of this paper is not to add another piece to the abundant literature on the econometric reliability of EAT. Rather, we want to move the focus of the analysis to the theory, and enquire as to the theoretical solidity of the expansionary austerity viewpoint. So far, a few works have tried to

\footnotetext{
${ }^{1}$ See Sutherland (1997) for the case of possible non-Keynesian effects of expansionary fiscal measures when undertaken in a context of high public debt. Perotti (2012) also stresses that fiscal contractions may be expansionary in the presence of high interest rates, in particular when they contribute to reducing risk premia on financial assets and prompt a considerable reduction in nominal interest rates, particularly with respect to government bonds.
} 
analytically underline the theoretical weaknesses of EAT from a heterodox perspective. In our view, these contributions are not completely satisfactory. On the one hand, they often rely on adhoc assumptions; on the other, they model austerity packages too roughly, without considering the specific policy measures composing them. In this paper, we try to fix these shortcomings by presenting a simple theoretical model.

The final goal of our model is twofold. First, we critically investigate the influential assertion by Alberto Alesina, according to which "many even sharp reductions of budget deficits have been accompanied and immediately followed by sustained growth rather than recessions even in the very short run" (Alesina 2010: 3; emphasis in the original). In this sense, we stress that the theoretical fundamentals and economic mechanisms of the EAT hypothesis are extremely fragile, and stateand institutional-contingent, to say the least. Second, we analyze the long-run dynamics possibly set in motion by austerity measures. Our aim is to criticize the idea that fiscal consolidations might imply short-term costs, but lead to far larger medium-to-long-run benefits in the form of safer and sounder public finances, stable or decreasing public-debt-to-GDP ratios, and revived economic activity as stimulated by booming investments in the private sector. ${ }^{2}$ We rather stress that austerityinduced short-run costs and long-run benefits may be inconsistent with each other. Indeed, even mild recessionary responses to adjustment programs may give rise to instable evolutions in the public-debt-to-GDP ratio, so that the short-run costs of austerity measures may eventually breed even larger long-run damages (rather than benefits).

Our model takes inspiration from the post-Keynesian and evolutionary/institutionalist tradition. From the post-Keynesian tradition, we take the demand-driven logic that permeates the functioning of our model. We also pay attention to the importance that mounting Keynesian-type radical uncertainty after the eruption of the sovereign debt crisis in the eurozone may have played and may still play in defining economic actors' expectations and behaviors. According to the evolutionary approach to systems dynamics (Radzicki and Sterman 1994), we describe an economy in which cumulative mechanisms may give rise to path dependence and multiple equilibria. We also put emphasis on the crucial role country-specific institutions play in shaping diverging economic trajectories. We note that austerity may lead to different outcomes depending on the specific "monetary environment" in which it is implemented. Whilst the short-run expansionary outcomes

\footnotetext{
${ }^{2}$ According to Warmedinger, Checherita-Westphal, and Hernandez de Cos (2015: 1), "the medium-to-longer-term benefits of well-designed fiscal consolidation are typically accompanied by short-term costs in the form of output losses, [but] since sound government finances are a prerequisite for price and macroeconomic stability and, consequently, for strengthening the conditions for sustainable growth, the long-term benefits of achieving such goals outweigh the short-term costs."
} 
of austerity measures hardly emerge in monetarily sovereign (say the US, the UK, Canada, or Japan) and non-monetarily sovereign countries (i.e., current eurozone member states) alike, the way central banks intervene to stop financial distress turns out to be a decisive factor in taming or feeding long-run macroeconomic instability. In the case of non-monetarily sovereign countries, in the absence of any deep institutional discontinuity, debt forgiveness may eventually emerge as the ultimate solution for restoring economic soundness. This fact notwithstanding, the changes in monetary institutions' commitments taking place in the eurozone since mid-2012 also show that economic variables and institutional factors may eventually co-evolve in response to existing economic problems. Such a joint endogenous evolution may give rise to structural breakthroughs in which new and much more stable dynamics set in; even though they may not be sufficient to result in a solid recovery, such a joint endogenous evolution may give rise to structural breakthroughs in which new and much more stable dynamics set in.

The paper is organized as follows. Section 2 develops the short-run part of our model. We model the well-designed consolidation packages advocated by the supporters of EAT, and analyze their impact on current economic activity and on the deficit-to-GDP ratio. Section 3 moves to the long run and shows how fiscal variables (and eventually economic institutions) may (co-)evolve through time as a consequence of (and perhaps in reaction to) the short-run effects assessed before. Section 4 concludes.

\section{SHORT-RUN EXPANSIONARY/CONTRACTIONARY EFFECTS OF FISCAL ADJUSTMENTS IN A SIMPLE OPEN ECONOMY}

To the best of our knowledge, only a few non-mainstream studies have aimed at analytically showing the intrinsic theoretical fragility of the EAT.

Robert Boyer (2012) surveys the specific conjunctures under which, in the past, austerity measures might have been expansionary in a few small, open economies. He stresses that there is "no general theoretical reason to guarantee the success of any austerity policy" (Boyer 2012: 297).

Nevertheless, Boyer does not provide any formal treatment of his point.

Palley (2010) elaborates a simple post-Keynesian demand-driven closed-economy model showing the short-run effects of fiscal rules imposing limits to the debt-to-GDP ratio. Dosi et al. (2015) present an evolutionary model featuring complex micro-macro interactions. They extend the scope 
of Palley's analysis by considering the long-run consequences that austerity-imposed ceilings on government deficits may exert on trend growth and macroeconomic volatility by affecting R\&D efforts and technology progress. Yet, both models have some common drawbacks. They are somehow unsuitable for confuting EAT on its own grounds since their theoretical frameworks engineer built-in contractionary outcomes of austerity measures. ${ }^{3}$

Foresti and Marani (2014) propose a simple short-run model in which austerity may have expansionary outcomes depending on the accommodative stance monetary policy may take in the presence of fiscal retrenchments. In doing this, however, they still superficially define austerity as a reduction in public deficit, this way taking the squeezing effects of fiscal consolidation on public deficit for granted.

In this paper, we propose an analytical treatment of the argumentative approach developed by Boyer (2012). With respect to Palley (2010) and Dosi et al. (2015), our model allows for a wider variety of results, so that EAT may be criticized more effectively by arguing about the implausibility of its own assumptions and mechanisms. With respect to Foresti and Marani (2014), our model is more detailed in the analysis of the specific policy measures composing well-designed austerity packages, but at the same time it is more general in the type of results it may give rise to (i.e., shrinking or widening fiscal deficits).

Let assume an open economy. Further, let assume that the economy does not work at full potential in order to allow for (fiscal) policy-driven expansions of aggregate demand and, hence, current economic activity. Indeed, EAT argues that well-designed fiscal adjustments can boost economic activity through both supply and demand channels. ${ }^{4}$ This fact notwithstanding, most of its emphasis is on demand-side channels, perhaps in order to stress its non-Keynesian perspective on the effects of fiscal policies. ${ }^{5}$ In line with this logic, and with the attempt to show its shortcomings, here we focus on the operativeness of the demand-side levers only.

\footnotetext{
${ }^{3}$ Palley (2010) and Dosi et al. (2015) consider a simple closed economy in which, by default, the "external channel" through which austerity is supposed to deliver some expansionary results is inoperative. Also, both models identify austerity with deficit-cutting rules. They do not enter into the details of what is considered a well-designed consolidation plan.

${ }^{4}$ Alesina and Ardagna (2010) argue that lower public-sector employment, lower public-sector wages, and (or) lower degrees of labor market protection (say cut in unemployment benefits) tend to reduce trade unions' bargaining power and to increase individual labor supply. In the context of supply-driven mainstream models, this may eventually stimulate growth by leading to an expanding aggregate supply.

${ }^{5}$ Alesina, Favero, and Giavazzi (2015) clearly point out that a decisive aspect of successful austerity packages lies in their capacity to stimulate the private sector's investments by fostering the private sector's confidence in the solidity of the domestic macroeconomic environment. Such a peculiar component of (successful) expenditure-based fiscal consolidations versus (unsuccessful) tax-based adjustments "cannot be explained by (accompanying) supply-side
} 
Our economy is composed of six sectors: working households, rentiers, (non-financial) firms, the government, commercial banks, and, ultimately, the "rest of the world" (RoW henceforth).

Working households get wages $(w)$ from non-financial firms. They consume domestic goods $(C)$, import foreign-made products, and pay taxes according to the tax rate $(t)$. They also receive public transfers $\left(\operatorname{Tr}^{G}\right)$ and unemployment benefits $(\bar{w} U)$ from the government. Working households' savings take the form of new deposits to commercial banks.

Rentiers get dividends from commercial banks, ${ }^{6}$ as well as interest payments on their holdings of foreign financial assets. For the sake of simplicity, we assume rentiers not to consume. Rentiers use their savings in order to accumulate new foreign financial assets according to a sort of Panama Papers-type investment fashion.

Non-financial firms pay wages to workers and make interest payments $\left(i_{H} L\right)$ on the stock of loans from commercial banks. They get revenues through workers' consumption expenditures, government purchases, exports to the RoW $(X E)$, and domestic gross capital formation $(I)$. Together with new loans $(d L)$ from commercial banks, realized profits $(\Pi)$ are fully retained ${ }^{7}$ in order to finance desired capital accumulation.

Commercial banks provide loans $(L)$ to domestic firms and buy domestic government bonds. Accordingly, they get interest payments $\left(i_{H} L\right)$ from domestic firms and $\left(i_{D} D^{H}{ }_{b}\right)$ from the government. Commercial banks receive deposits from households. We assume interest rates on households' deposits to be equal to zero. Commercial banks' profits are fully redistributed to rentiers. New equity issuances are not considered in the present paper.

The government undertakes current consumption expenditures $(G)$, and makes transfers to working households. It also levies taxes on working households' income. In the expansionary austerity literature, taxes on households' income represent a crucial component of "well-designed" austerity packages. Alesina and Perotti (1997) argue that successful fiscal consolidations ("type-1 adjustments," in the jargon of the authors) "rely primarily on expenditure cuts, in particular cuts in

reforms" (Alesina, Favero, and Giavazzi 2015: 37); it implicitly relies upon the existence of a "negative" fiscal multiplier of aggregate demand.

${ }^{6}$ We assume rentiers to be the ultimate owners of commercial banks by holding commercial banks' equities.

${ }^{7}$ In the age of financialization of non-financial firms and increased shareholder value orientation, this represents a strong assumption. Yet, it is fully consistent with the focus of this paper on the macroeconomic effects of austerity measures rather than on the intrinsic evolution of modern capitalist economies. This assumption does not reduce in any way the degree of generality of our analysis, whilst it makes it more tractable from a mathematical point of view. 
transfers, social security, government wages, and employment [whilst] tax increases are a small fraction of the total adjustment, and, in particular, taxes on households are not raised at all or are even reduced" (Alesina and Perotti 1997: 211). On the contrary, contractionary "type-2 adjustments rely mostly on broad-based tax increases, and often the largest increases are in taxes on households and social security contributions" (Alesina and Perotti 1997: 211). ${ }^{8}$ Consistent with this logic, here we will critically enquire whether, and under which conditions, spending cuts could be successfully matched with (expected) reductions in households' taxes in order to make fiscal consolidations expansionary. For the sake of simplicity, we do not include taxes on rentiers' income or firms' profits (or indirect taxes) in our model.

The difference between the government's revenues and total expenditures gives public surplus (or deficit). Public deficit is financed by issuing new government bonds $(B=d D)$. Both commercial banks and the RoW buy domestic government bonds.

As to international trade flows, the RoW sells us imported goods in the amount $(X M)$ and buys exports $(X E)$. As to financial transactions, financial outflows are given by domestic rentiers' accumulation of new assets abroad. Financial inflows take the form of net purchases of new homegovernment bonds by the RoW (i.e., $\left[B_{R o W}=d D_{R o W}^{H}\right]$ ). In this regard, the decision of foreign investors to buy home-government bonds (rather than "keeping their money abroad") relies upon the well-known uncovered interest rate parity (UIP). Exchange rate fluctuations, and the ensuing exchange rate risk, constitute a relevant factor in defining the UIP. For the sake of simplicity, here we depart from this complication and do not explicitly take into account exchange rate dynamics in determining, through the UIP, the interest rate on home-government bonds (see below). In the specific case of eurozone countries, this assumption is justified by the fact that intra-eurozone financial flows are not affected by any consideration (or concern) about exchange rate dynamics.

\subsection{The Model}

Let assume the economy produces according to a fixed-coefficient production technique. Equation (1) defines the current level of economic activity $(Y)$ as a function of the level of capacity utilization $\left(y=Y / Y^{*}\right),{ }^{9}$ the output-capital technological coefficient $\beta\left(=Y^{*} / K\right)$, and of the available capital stock $(K)$.

\footnotetext{
${ }^{8}$ Alesina and Perotti (1997) also stress that spending cuts matched with (expected) reductions in household taxes may lead to expansionary outcomes by reducing workers' wage claims, by inducing wage moderation, and hence by increasing the external competitiveness of domestically produced goods.

${ }^{9} Y^{*}$ stands for potential output, i.e., the maximum amount of output the economy could produce by fully utilizing the available capital stock.
} 


$$
Y=\frac{Y}{Y^{*}} \frac{Y^{*}}{K} K=y \beta K
$$

Given labor productivity $(\alpha)$ and the total labor force $(N)$, equations (2) and (3) define the level of unemployment $(U)$ and the unemployment rate $(u)$, with $(\delta)$ as the ratio of potential output over the maximum amount of goods producible according to labor productivity and the available labor force. $^{10}$

$$
\begin{aligned}
& U=N-E=N-(Y / \alpha) \\
& u=\frac{N-(Y / \alpha)}{N}=1-\frac{Y}{Y^{*}} \frac{Y^{*}}{\alpha N}=1-\delta y
\end{aligned}
$$

As far as the labor market is concerned, we assume workers and trade unions to target a desired real wage rate and therefore, given labor productivity, a desired wage share $\left(1-\tau_{w}\right)$ (" $\tau_{w}$ " being the profit share implicitly consistent with the trade unions' target). We assume the bargaining power of trade unions to positively depend on the degree of regulation and protection of workers in the labor market, say the generosity of unemployment benefits $(\bar{w})$, among other factors. Accordingly, we assume $\left(1-\tau_{w}\right)$ to be a positive function (and, correspondingly, $\tau_{w}$ a negative one) of the "labor market regulation variable" $(z)$. Equation $(4)$ defines the nominal wage rate $(w)$ bargained by trade unions on the basis of their targeted wage share and their price expectations $\left(P^{e}\right)$ :

$$
w=\left(1-\tau_{w}(z(\bar{w})) P^{e} \alpha\right.
$$

On their side, firms target a desired profit rate $\left(r^{d}\right)$. Given their expectations about the level of capacity utilization $\left(y^{e}\right)$ - see more on this below-they set the mark-up $(m)$ on variable costs and the ensuing profit share $(\tau)$ on domestic income consistently with their goals. Equations (5) and (6) formalize firms' behavior and its implications in terms of the price-setting rule of the domestically produced good's price $\left(P^{H}\right)$ :

$$
\begin{aligned}
r^{d} & =\tau(m) y^{e} \text { hence } m=\tau\left(r^{d} / y^{e}\right)^{-1} \text { with }\left(\partial \tau / \partial r^{d}\right)>0 ;\left(\partial \tau / \partial y^{e}\right)<0 \\
P^{H} & =(1+m) w / \alpha
\end{aligned}
$$

\footnotetext{
${ }^{10}$ In this model, we assume that possible bottlenecks taking place on the supply side of the economy take the form of shortage of productive capital rather than, strictly speaking, shortage of labor. Therefore, the economy will be always characterized by a certain, say, structural degree of unemployment.
} 
In our open economy, equations (5) and (6), together with foreign prices $\left(P^{F}\right)$ and the nominal exchange rate $(e)$ concur to determine the real exchange rate $(q)$; see equation $(7)$, below:

$$
q=\frac{e P^{F}}{P^{H}}=\frac{e P^{F}}{(1+m)\left(1-\tau_{w}\right) P^{e}}
$$

Now that we have described the production side of the economy, let's analyze the components of aggregate demand. As to domestic consumption, let's first assume it is a positive function of working households' disposable income. Disposable income in turns depends on the wage bill [ $W$ $(=w E)$ ], public transfers $\left(\operatorname{Tr}^{G}\right)$, and unemployment benefits $(\bar{w} U)$. Once taxes are paid according to the taxation rate $(t)$, a proportion of disposable income $(s)$ is saved. Consumption expenditures are then allocated to domestic and imported goods according to the spending shares $\eta(q)$ and $(1-\eta)$, respectively, $\eta$ being a positive function of the real exchange rate $(q)$. Equation (8) eventually defines consumption demand for domestically produced goods normalized by the domestic capital stock:

$$
\frac{C}{P^{H} K}=(1-s)(1-t) \eta\left[\frac{\beta}{\alpha}(\omega-\bar{\omega}) y+\frac{\beta}{\alpha} \bar{\omega}+\rho\right]
$$

With $\omega\left(=w / P^{H}\right)$ and $\bar{\omega}\left(=\bar{w} / P^{H}\right)$ as the real wage rate and the real unemployment benefit (in terms of the price of the domestically produced goods) - with $>\bar{\omega}$ and $\rho\left(=\operatorname{Tr}^{G} / P^{H} K\right)$.

In line with the literature on expansionary austerity, we assume that, according to, say, a permanent income argument, households' saving propensity $(s)$ depends positively on the expected future tax rate $\left(\mathrm{t}^{\mathrm{e}}\right)$. Current cuts in public expenditures, if sufficiently strong and reliable, may induce households to increase current consumption, since they may expect a lower tax burden tomorrow. By the same token, we also assume the saving propensity of households to depend negatively on public transfers. Indeed, it is reasonable to believe that a permanent cut in public transfers, perhaps due to the decision to downsize the provisions of the welfare system (read: a less-generous domestic pension system), may also induce households to adopt a precautionary stance and save more today in anticipation of lower public transfers tomorrow. ${ }^{11}$ Equation (9), below, puts the above considerations in formal terms:

\footnotetext{
${ }^{11}$ The same logic may apply in the presence of a reduction in public benefits to unemployed people, which perhaps makes average expected income lower.
} 


$$
s=f\left(t^{e}, \operatorname{Tr}^{G}\right) \text { with }\left(\partial s / \partial t^{e}\right)>0 ;\left(\partial s / \partial T r^{G}\right)<0
$$

Equation (10) gives public purchases, once again normalized for the existing capital stock $K$, as an exogenous policy variable $(\gamma)$.

$$
\frac{G}{P^{H} K}=\gamma
$$

Equation (11) defines the current growth rate of the capital stock. For the sake of simplicity, following Taylor (2012), we assume that investment demand is purely autonomous in the short run, so that it does not depend on current capacity utilization. Perhaps consistently with a Harrodian interpretation of Keynesian macroeconomics, and in order to capture the "expectation argument" put forward by EAT, we first imagine entrepreneurs define the desired increase in the available capital stock according to their expectations about capacity utilization $\left(y^{e}\right) .{ }^{12}$ On the one hand, entrepreneurs will increase investments should they expect the economy to expand and capacity utilization to be high in the future. On the other, they will scale down investment projects if a vulnerable and unsound macroeconomic environment spreads expectations about contracting economic activity.

We also assume investment demand to be a negative function of the costs of external borrowing $\left(i_{H}\right)$. Once again, this assumption aims at formalizing one of the pillars of the expansionary austerity building, i.e., the expansion in private investments possibly triggered by austerity measures prompting a reduction in interest rates.

$$
\frac{I}{K}=g\left(y^{e}, i_{H}\right)
$$

With $g_{y^{e}}>0$ and $g_{i_{H}}<0$.

Finally, in equation (12), we assume normalized exports to be a simple linear positive function of the real exchange rate $(q)$.

$$
\frac{E X}{P^{H} K}=\epsilon q
$$

\footnotetext{
${ }^{12}$ See again the recent contribution by Alesina, Favero, and Giavazzi (2015) on the crucial role entrepreneurs' expectations, and hence investment, may play in giving rise to what they interpret as examples of (spending-based) expansionary fiscal consolidations.
} 
As to the "financial" side of the economy, let first consider how private firms finance their desired investment expenditures. In this model, we assume that non-financial firms retain all profits in order to fund capital accumulation. Additionally, they take loans from commercial banks $(d L)$ for the part of investments not covered by internal funds. In the real life, it is obviously possible that commercial banks ration available credit so that not all investment projects are eventually financed. For the sake of simplicity, we do not take this eventuality explicitly into account. Nonetheless, commercial banks fix the interest rate $\left(i_{H}\right)$ charged on loans to non-financial firms. In periods of financial distress, commercial banks are very likely to increase the mark-up rate through which they determine $i_{H}$ (see more on this below). By doing this, they increase the cost of external financing of non-financial firms' investments, and implicitly cut the total amount of financed investment projects. $^{13}$

Commercial banks hold two types of assets on their balance sheet. On the one hand, they buy domestic government bonds; on the other, they give loans to firms. Government bonds are considered "relatively" safe assets. Indeed, they constitute the collateral commercial banks commonly use in refinancing operations with the central bank, even in periods of financial turbulences in the market for sovereign bonds. On the contrary, loans to firms are considered as "relatively" riskier. Following Mehrling (2011), commercial banks may not be allowed to shift loans made to the private sector onto the balance sheet of the central bank or of other financial institutions. Once created, loans to the private sector will likely remain on the commercial bank's balance sheet until maturity, together with the corresponding creditor risk. Accordingly, we assume commercial banks to set the interest rate $\left(i_{H}\right)$ on loans to the private sector by applying a mark-up $(\mu)$ on the interest rate $\left(i_{d}\right)$ received on government bonds [see equation (13)]. ${ }^{14}$

$$
i_{H}=(1+\mu) i_{d}
$$

Public deficit and, hence, new bond issuances, are given by the difference between the government's outlays [i.e., public purchases, public transfers, unemployment benefits, and interest payments on the accumulated public debt stock $(\Psi)]$ and tax revenues. The following expression (14a) defines public deficit in nominal terms, whilst equation (14b) normalizes it by the capital stock:

\footnotetext{
${ }^{13}$ In our model, commercial banks do not set a limit on the number of projects they could potentially finance by changing the position of the effective demand for credit on the credit market, but by moving along the effective demand curve for credit by fixing a higher interest rate on available credit.

${ }^{14}$ Alternatively, one can also interpret such a mark-up rate $(\mu)$ as the natural spread dividing interest rates on riskier assets (i.e., private loans) from those charged on safer ones (i.e., government bonds).
} 
(14a) $d D=G+T r^{G}+\bar{w} U-t\left[w E+\operatorname{Tr}^{G}+\bar{w} U\right]+\Psi$

Hence:

$$
\frac{d D}{P^{H} K}=\gamma+(1-t)\left(\rho+\bar{\omega} \frac{\beta}{\alpha} \delta\right)-[t \omega+(1-t) \bar{\omega}] \frac{\beta}{\alpha} y+\psi=\xi+\psi
$$

with $(\xi)$ as the primary deficit-to-capital-stock ratio, and $(\psi)$ as the costs of debt servicing over the capital stock.

Finally, equation (15) formalizes how the interest rate on government bonds is determined on the financial and credit market in the simplest way possible.

$$
i_{d}=i+\sigma(b, \Omega)
$$

with:

$\sigma>0$ and $(\partial \sigma / \partial b)>0$ if $\Omega=1$

$\sigma=0$ and $(\partial \sigma / \partial b)=0$ if $\Omega=0$

Given the supply of new bonds given by public-sector financing needs, bids for bonds by domestic commercial banks and foreign investors depend on the perceived degree of soundness of public finances, and the level of safety of the corresponding financial liabilities. In turn, the riskiness of government bonds likely relies upon the "monetary framework" in which government bonds are issued. Following De Grauwe (2011), monetarily sovereign countries issue bonds denominated in their own currency, which is in turn controlled by the corresponding central bank. Even more importantly, the central bank will likely intervene in financial markets any time it likes and buy government bonds in order to prevent default risks from emerging. Accordingly, in monetarily sovereign countries, government bonds are usually considered risk-free assets. Of course, this is not the case of eurozone economies. Indeed, eurozone governments issue bonds denominated in a foreign supranational currency outside their own (direct or indirect) control. On top of this, eurozone rules require national governments to find resources on private financial markets only, and forbid the European Central Bank (ECB) from buying public bonds (at least on the primary market). In a way, the solidity of the eurozone's national finances is subject to the will of financial 
operators. Accordingly, financial operators perceive the eurozone's government bonds as potentially riskier assets.

Consistent with these arguments, in equation (15) the interest rate on government bonds is established by the behavior of financial markets according to the UIP. In equation (15), $(i)$ stands for the interest rate on risk-free assets. Parameter $(\sigma)$ represents a country-specific factor risk. It jointly depends on the state of public finances, and on country-specific "monetary institutions" arrangements." In particular, we assume $\sigma$ to depend positively on the public-deficit-to-GDP ratio, $b=(\xi+\psi) / \beta y .^{15}$ The higher $b$ is, the higher the interest rate national governments will have to pay on issued public bonds will be. This relationship, however, holds true only in the case of nonmonetarily sovereign economies, i.e., when the bivariate "institutional variable" $(\Omega)$ is equal to 1 . Following De Grauwe and Ji (2013), in the case of monetarily sovereign economies (i.e., when $\Omega=0$ ) this relationship breaks down and government bond yields become insensitive to economic fundamentals such as the fiscal policy stance (read public deficit), the growth rate of the economy, and its net external investment position. ${ }^{16}$ Accordingly, government bonds get the "status" of riskfree assets, and the corresponding interest rate is exogenously set equal to $(i)$.

\subsection{The Short-run Macroeconomic Effects of Cuts in Public Transfers}

The supporters of the expansionary austerity stress that well-designed fiscal consolidations must take the form of deep, persistent, and credible cuts in public expenditures, in particular public transfers and wages of public employees, perhaps followed by reductions in the tax burden on households. In their view, such a shift in fiscal policy may constitute a "regime change" that can immediately foster economic activity through three main mechanisms. First, successful fiscal corrections can positively affect the behavior of private economic actors, both households and firms, through the so-called "expectation channel." Upfront public spending cuts, it is argued, may induce economic agents to form optimistic expectations by anticipating future tax reductions and consequent increases in their own (permanent) income. This, in turn, may incentivize them to immediately raise consumption and to unleash new investments, giving momentum to current economic activity. Second, tough fiscal corrections that prove to be effective in reducing public deficit and public debt stock can stimulate investments and growth by reestablishing bond

\footnotetext{
${ }^{15}$ In this model, we assume the interest rate $\left(i_{d}\right)$ to be a (positive) function of the public-deficit-to-GDP ratio only, and not of the debt-to-GDP ratio. This is, of course, a simplifying assumption. Yet, whilst it makes mathematical passages more tractable, it does not change the meaning or the results of our analysis. This assumption will be relaxed in the long-run analysis performed in the second part of the paper.

${ }^{16}$ De Grauwe and Ji (2013) stress that "[in the case of 'stand-alone' economies] financial markets do not seem to be concerned with the size of the government debt and of the fiscal space [...] despite the fact that the variation of these ratios is of a similar order of magnitude as the one observed in the eurozone" (De Grauwe and Ji 2013: 24).
} 
vigilantes' trust in the solvency of public finances and prompting a significant reduction in interest rates. Finally, cuts in public wages can foster exports by establishing a climate of wage moderation in the labor market, hence engineering an internal and external devaluation.

In our theoretical framework, equation (16) defines the level of capacity utilization (y) that ensures equilibrium in the goods market:

$$
y=\frac{(1-s)(1-t) \eta(q)\left(\bar{\omega} \frac{\beta}{\alpha}+\rho\right)+\gamma+g\left(y^{e}, i_{H}\right)+\epsilon q}{\left[\beta-(1-s)(1-t) \eta \frac{\beta}{\alpha}(\omega-\bar{\omega})\right]}
$$

More than that, equation (16) represents the crucial economic relation through which we can theoretically inquire about the effectiveness of well-designed austerity packages in prompting economic recovery in the short-run.

In order to perform such analysis, let's first assume the government implements a restrictive fiscal adjustment such that the cyclically adjusted primary deficit over GDP decreases by an amount equal to $-\theta$. Also assume that fiscal consolidation mainly consists of cuts to public transfers (i.e., $d T r^{G}<$ $0)$. In terms of our model, once defined, the CAPB-to-GDP ratio is $b^{*}=\frac{1}{\beta}[\gamma+(1-t)(\rho+$ $\left.\left.\bar{\omega} \frac{\beta}{\alpha} \delta\right)-[t \omega+(1-t) \bar{\omega}] \frac{\beta}{\alpha}\right]$, we get:

$$
d b^{*}=-\theta=\frac{(1-t)}{\beta} d \rho=\frac{(1-t)}{\beta P^{H} K} d \operatorname{Tr}^{G}, \text { so that: } d \operatorname{Tr}^{G}=-\frac{Y^{*}}{(1-t)} \theta
$$

with $\theta>0$.

In our model, such a fiscal adjustment has a direct and simultaneous short-run effect on both current capacity utilization $(y)$ and $(b)$. Totally differentiating $y$ and $b$, and taking into account the sign of equation (17), we get a system (S.1) of two simultaneous equations for $d y$ and $d b$ :

$$
\left\{\begin{array}{c}
d y=\frac{-\left[f_{t} e(1-t) \eta\left(\bar{\omega} \frac{\beta}{\alpha}+\rho\right) d t^{e}-f_{T r} \eta\left(\bar{\omega} \frac{\beta}{\alpha}+\rho\right) Y^{*} \theta\right]-(1-s) \eta Y^{*} \theta-g_{i_{H}}(1+\mu) \sigma_{b} d b}{\left[\beta-(1-s)(1-t) \eta \frac{\beta}{\alpha}(\omega-\bar{\omega})\right]} \\
d b=-\frac{Y^{*}}{\beta y} \theta-[t \omega+(1-t) \bar{\omega}+b] \frac{d y}{y}
\end{array}\right.
$$

with $f_{t^{e}}>0 ; f_{T^{G}}<0 ;\left(\sigma_{b} \mid \Omega\right) \geq 0 ; d t^{e}<0$ 
Equations (18) and (19) give the solutions $d y^{S}$ and $d b^{S}$ of system (S.1):

$$
\begin{aligned}
& d y^{S}=\frac{\overbrace{\frac{\left.f_{t^{e}}(1-t) \eta\left(\bar{\omega} \frac{\beta}{\alpha}+\rho\right)\right]\left|d t^{e}\right|}{+o r}-\overbrace{\left[(1-s)-f_{T r}\left(\bar{\omega} \frac{\beta}{\alpha}+\rho\right)\right] \eta Y^{*} \theta}+\overbrace{g_{i_{H}}(1+\mu) \frac{Y^{*}}{\beta y} \sigma_{b} \theta}^{+ \text {or } \theta}}^{-}}{\left\{\left[\beta-(1-s)(1-t) \eta \frac{\beta}{\alpha}(\omega-\bar{\omega})\right]-g_{i_{H}}(1+\mu) \sigma_{b}\left[\frac{t \omega+(1-t) \bar{\omega}+b}{y}\right]\right\}} \\
& d b^{S}=-\frac{Y^{*} \theta}{\beta y}-[t \omega+(1-t) \bar{\omega}+b] \frac{d y^{S}}{y}
\end{aligned}
$$

What emerges from equations (18) and (19) is that there is not any clear outcome of fiscal austerity. Indeed, the sign of equation (18) may be positive, confirming the expansionary austerity hypothesis, or negative, in line with the traditional Keynesian concern about the recessionary effects of fiscal retrenchments. The same applies to equation (19). Cuts in public transfers might help in reducing public deficit over GDP or, alternatively, they may be counterproductive and lead to an even higher deficit-to-GDP ratio in the event they trigger a deep economic contraction. In the end, the introduction of expansionary austerity-like assumptions in our model, and the detailed formalization of what is considered a well-designed austerity package, does not at all guarantee austerity measures to be effective.

Despite such indeterminacy, some worrisome points are worth stressing. First, the expansionary outcome of fiscal adjustments heavily depends on the intensity of partial derivative $f_{t} e$, and of $\left|d t^{e}\right|$, i.e., the expected reduction in the tax rate levied on households. The higher and the quicker $\left|d t^{e}\right|$ is, the more rapidly and robustly private consumption may positively respond to cuts in public budgets. Interestingly, and perhaps paradoxically, it is reasonable to think that such positive expectations will hardly materialize in an economy characterized by a high public debt stock, i.e., the economic scenario in which, according to EAT supporters, fiscal consolidation is primarily needed. Indeed, when public debt $(D)$ is considerably high and a prolonged period of fiscal consolidation is foreseen, a high degree of uncertainty may "surround" the extent and the timing of future tax cuts (at least with respect to current certain spending cuts). In such a context, the "expectation channel" is extremely weak at best, and likely more than compensated by the overwhelming contractionary effect of cuts in current public transfers.

Second, expansionary austerity proponents say cuts in public transfers can boost growth by reducing public deficit, hence the interest rate $\left(i_{d}\right)$ on public bonds and, above all, the interest rate $\left(i_{H}\right)$ on loans banks make to the private sector. Such a reduction in the cost of external borrowing 
may in fact spur private investment, and induce the economy to expand. According to our model, however, such an effect of fiscal adjustments on interest rates does not take place in monetarily sovereign economies. Following equations (13) and (15), in the case of monetarily sovereign countries, the "financial market channel" seems to be irrelevant (i.e., $\sigma_{b}=0$ ), and the alleged expansionary impact of fiscal consolidation turns out to be even more questionable.

The "financial market channel" might be at work in the case of eurozone countries that issue public bonds denominated in a supranational currency, and in which the solidity of public finances hinge upon the sentiments of financial markets. In such a context, one could be persuaded that frontloaded fiscal adjustments might reassure financial markets about the sustainability of the fiscal positions of eurozone countries, and thus create a favorable economic environment for growth. This logic may hold true if fiscal adjustments effectively put fiscal variables under control. Yet, we are very far from taking such an outcome of fiscal consolidation as guaranteed. Indeed, recent empirical evidence shows that it is hard to find a way out from public balance deficits without sustained growth (Ali Abbas et al. 2013), and that fiscal multipliers may be high and positive when economies are in the midst of a recession (Batini, Callegari, and Melina 2012; Baum, PoplawskiRiberio, and Weber 2012; Qazizada and Stockhammer 2015). If so, severe and perhaps premature fiscal retrenchments may actually induce a short-run deterioration in fiscal variables by jeopardizing growth (see Ali Abbas et al. 2013).

More formally, let us assume an economy in which: (a) the "credibility channel" is strong, and financial operators overreact to changes in public deficits (i.e., $\sigma_{b}>>0$ ); and (b) improvements in the public balance are overdependent on changes in economic activity [i.e., $(t \omega+(1-t) \bar{\omega}+b) / y$ $>>0$. In such a scenario, the denominator of equation (18) likely turns out to be negative. Despite the fact that discretionary budget cuts could reduce public deficits per se, even a small contraction in economic activity eventually makes public deficits deeper instead of smaller. Financial operators get even more frightened by worsening public finance conditions, and interest rates skyrocket. The economic recession gets deeper and gives rise to an endless "race to the bottom" (see figure 1), which will inevitably end up in a public debt default and a tremendously painful crisis. These kinds of dynamics may sadly resemble that ones observed in Greece since 2010. The message to policymakers is: in the context of non-monetarily sovereign countries, in which the "financial channel" is judged to be relevant for stabilizing real and financial variables, it is of paramount importance to assess the effectiveness of austerity packages in prompting quick recoveries before implementing them. Even if a mild recession is like to occur, austerity measures may give rise to a financial disaster rather than improving the soundness of public finances. 
Figure 1: Austerity-led “endless” economic contraction and explosive deficit-to-GDP ratio in an unstable short-run setting

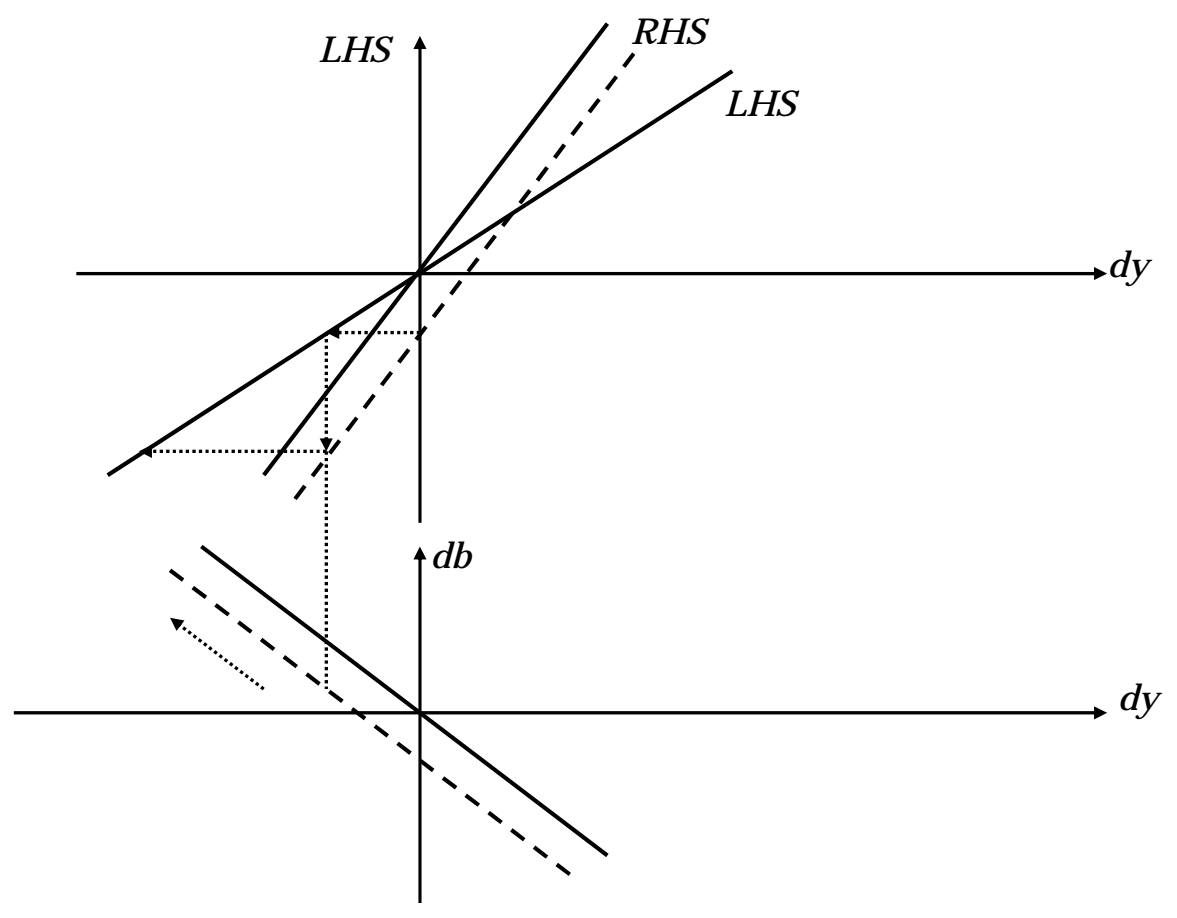

Finally, since mid-2012, financial speculation on the bonds of peripheral eurozone countries has calmed down thanks to Mario Draghi’s well-known "whatever it takes" pledge. Interest rates $\left(i_{d}\right)$ have decreased significantly. They are currently at historically low levels. In such a context, it makes sense to question the effectiveness of the "financial channel." As Roberto Perotti himself stresses, "if fiscal consolidations were expansionary in the past because they caused a steep decline in interest rates or inflation, it is unlikely that the same mechanism can be relied on in the present circumstances, with low inflation and interest rates close to zero" (Perotti 2012: 309).

\subsection{The Short-run Macroeconomic Effects of Lower Unemployment Benefits}

An additional proposition of EAT is that fiscal adjustments should also aim at reforming the labor market, directly or indirectly. For instance, cuts in unemployment benefits $(\bar{w})$ may induce wage moderation. This, in turn, may improve the external competitiveness of the economy and boost growth via rising exports and a decrease in imports. In our model, system (S.2) captures the shortrun effects of such additional fiscal austerity measures: 


$$
\left\{\begin{array}{c}
d y=\frac{\overbrace{}}{\frac{-}{(1-s)(1-t) \eta(\beta / \alpha)\left[(1-y) \bar{\omega}+\omega y \varepsilon_{w, \bar{w}}\right](d \bar{w} / \bar{w})}+\overparen{+} \frac{+}{\left[\beta-(1-s)(1-t) \eta \frac{\beta}{\alpha}(\omega-\bar{\omega})\right]}} \\
d b=\frac{\beta}{\alpha}\left[(1-t)(\delta-y) \bar{\omega}+t y \omega \varepsilon_{w, \bar{w}}\right] \frac{d \bar{w}}{\bar{w}}-[t \omega+(1-t) \bar{\omega}+b] \frac{d y}{y}
\end{array}\right.
$$

With $\Gamma=(1-s)(1-t)\left\{\frac{\beta}{\alpha}[\bar{\omega}+(\omega-\bar{\omega}) y]+\rho\right\} ;(\partial w / \partial \bar{w})>0$ and $\varepsilon_{w, \bar{w}}$ as the elasticity of nominal wages $(w)$ to the unemployment subsidy $(\bar{w}) ;(\partial q / \partial w)<0 ; d \bar{w}<0$.

Equations (20) and (21) give the solutions of system (S.2):

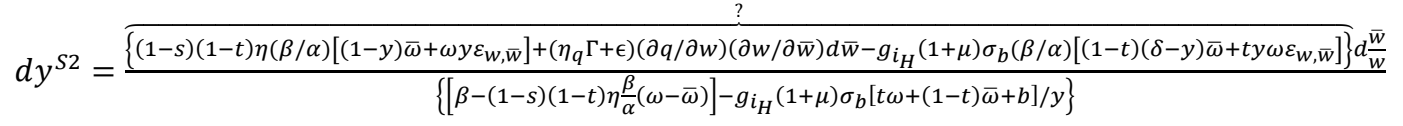

$$
d b^{S 2}=\frac{\beta}{\alpha}\left[(1-t)(\delta-y) \bar{\omega}+t y \omega \varepsilon_{w, \bar{w}}\right] \frac{d \bar{w}}{\bar{w}}-[t \omega+(1-t) \bar{\omega}+b] d y^{S 2}
$$

Once again, it is evident than no clear-cut solutions exist, and that the theoretical basis of EAT is extremely weak. In particular, when the direct and indirect effects [i.e., the decrease in monetary wages $(w)$ ] of cuts in unemployment benefits are taken into account, the immediate outcome of such measures is a lower demand injection (i.e., lower consumption). This would certainly deepen a recession instead of prompting recovery. Of course, the contraction in domestic consumption might well be compensated for by an increase in exports (and a decrease in imports) as boosted (discouraged) by lower domestic nominal wages ( $w$ ), and thus, ceteris paribus, by a depreciated real exchange rate $(q)$. However, increasing net exports and, possibly, booming economic activity strongly rely upon the sensitiveness of net exports to the real exchange rate [i.e., parameters $\epsilon$ and $\eta_{q}$ in equation (20)], which, in turn, is conditional on the sectorial composition of net exports themselves and the degree of openness of the economy (see Taylor 1991). It is perhaps not by chance that one of the most-cited examples of successful expansionary austerity is the one that took place in Ireland in late 1980s. Ireland is now a small, open economy that is highly integrated on the international goods markets, and exports a restricted but dynamic variety of manufactured products. At the end of the 1980s, Irish exports were already accounting for more than 50 percent of the Irish GDP. A fundamental pillar of the late 1980s Irish economic rebound was the solid expansion of Irish exports, also due to a significant initial one-shot devaluation of the Irish pound (Perotti 2012). At least in the case of eurozone countries, such a policy recipe is not available any longer. On top of 
this, it is questionable whether a relatively closed and largely deindustrialized small country like Greece could follow a similar recovery strategy. There are good reasons to believe that EATsponsored internal devaluation in Greece would give rise to the opposite result with respect to that supposedly generated by wage moderation in Ireland in the 1980s, when Irish wage moderation was combined with other available policy options that are no longer available, and when it was implemented in a much more favorable domestic and international economic scenario.

\section{THE LONG-RUN DYNAMICS}

Even admitting that austerity measures may imply some costs in the short run, the supporters of expansionary austerity nevertheless claim that well-designed fiscal consolidations can pave the way for bigger benefits in the medium-to-long run. These benefits are supposed to emerge from the allegedly safer macroeconomic environment austerity could lead to by putting public finances under control.

In order to critically assess such a proposition, let us analyze the dynamics of some relevant economic variables. Take price dynamics first. On the basis of equations (5)-(6), let us assume for the sake of simplicity that workers ground their price expectations on domestic prices only, so that $P^{e}=\left(P^{H}\right)^{e}$. Even further, let us assume that both the targeted real wage by trade unions and the desired profit rate by non-financial firms are exogenous and do not change through time. Consistently with these assumptions, trade unions modify their (nominal) wage claims should any gap be registered, ex post, between expected prices and effective ones (i.e., should their targeted wage share be inconsistent with the share eventually determined by the price-setting decisions of non-financial firms). ${ }^{17}$ More formally (with "hat variables" representing percentage variations):

$$
\widehat{w}=\frac{P^{H}-P^{e}}{P^{e}}=\left[\left(1+m\left(r^{d} / y^{e}\right)\left(1-\tau_{w}\right)-1\right]\right.
$$

Non-financial firms may decide to change their mark-up if their expectations about capacity utilization, and hence their targeted profit rate, are not fulfilled. In particular, we could write:

$$
(\widehat{1+m})=\tau \widehat{m}=\tau \vartheta\left(\tau y^{e}-\tau y\right)=\tau^{2} \vartheta\left(y^{e}-y\right)
$$

\footnotetext{
${ }^{17}$ It is easy to verify that the condition $P^{H}=\left(P^{H}\right)^{e}$ implies $(1+m)\left(1-\tau_{w}\right)=1$, hence $\left(1-\tau_{w}\right)=\frac{1}{1+m}=(1-\tau)$, where $(1-\tau)$ is workers' wage share, effectively emerging in the economy once firms have set prices according to their expectations and desired profit rate.
} 
In equation (23), $\vartheta$ stands for the extent by which non-financial firms adjust their mark-up rate $(m)$ as a consequence of unrealized expectations. Non-financial firms may increase their mark-up rate $(m)$ in the attempt to raise profitability from unsatisfactorily low levels, due to an effective capacity utilization lower than expected (i.e., $y^{e}>y$ ). Alternatively, firms may be satisfied by a slightly lower mark-up rate should economic activity be buoyant and competitive pressures increasing. ${ }^{18}$ Equation (24) defines domestic price inflation by combining equations (22) and (23):

$$
\widehat{P^{H}}=\tau^{2} \vartheta\left(y^{e}-y\right)+\left[\left(1+m\left(r^{d} / y^{e}\right)\left(1-\tau_{w}\right)-1\right]\right.
$$

According to EAT, the formation and evolution of expectations plays a crucial role for austerity packages to be expansionary. In EAT, the formation of expectations follows a standard forwardlooking, perfect-foresight logic as elaborated by fully rational economic actors. Such a theoretical apparatus significantly downgrades the degree of uncertainty affecting economic actors' decisions. It excludes by assumption the systemic risks, and the occurrence of long-lasting periods of economic depression/stagnation possibly triggered off by financial crises and public debt defaults.

The theoretical infrastructure just described seems quite unrealistic and incapable of representing the worldwide economic scenario emerging in the aftermath of the 2007-08 financial meltdown. For sure, it is unsuitable for describing the climate of economic and political havoc characterizing the eurozone since the beginning of 2010. In the last five years, economic decisions in the eurozone have been made in a condition of deep substantive and procedural uncertainty (Dosi and Egidi 1991). First, economic actors did not possess clear information about the real solidity of member states' public finances, and about the extraordinary policy measures repeatedly announced to restore fiscal soundness. Second, they did not know how to elaborate on such information in light of the spreading pessimism about eurozone survival. Given the ensuing climate of radical uncertainty, the best economic actors could (can) do was to elaborate on expectations in a myopic fashion. This is formally stated in equation (25), which models how non-financial firms' expectations evolve:

$$
\widehat{y^{e}}=\phi\left(y-y^{e}\right)=\phi\left(y\left(y^{e}, \lambda\right)-y^{e}\right)
$$

Non-financial firms revise upward their expected level of capacity utilization, and hence set $\widehat{y^{e}}>0$, when current capacity utilization $(y)$ turns out to be higher than the expected one. On the

\footnotetext{
${ }^{18}$ See Taylor (2004: ch.3) for a review of the literature assuming the mark-up rate to be a negative function of capacity utilization.
} 
contrary, should effective capacity utilization be less than expected, expectations will be adjusted downward.

Two different stability scenarios may characterize the dynamics of expectations. On the one hand, a self-stabilizing adjustment process prevails if current economic activity, via desired investments, does not overreact to changes in expectations. Mathematically, this scenario takes place if $\left.\left(\partial \widehat{y^{e}} / \partial y^{e}\right)<0\right)$, i.e., if the following condition $\frac{g_{y^{e}}}{\left[\beta-(1-s)(1-t) \eta_{\alpha} \frac{\beta}{\alpha}(\omega-\bar{\omega})\right]}<1$ is fulfilled. On the other hand, should $\frac{g_{y^{e}}}{\left[\beta-(1-s)(1-t) \eta_{\alpha}^{\beta}(\omega-\bar{\omega})\right]}$ be greater than 1 , and $\left(\partial \widehat{y^{e}} / \partial y^{e}\right)>0$, overly optimistic (overdepressed) investment decisions will respond to improving (worsening) expectations. In this event, the revision of expectations would be characterized by unstable knife-edge Harrodian dynamics.

With respect to the short-run model described above, in equation (25) we introduction an additional EAT-like assumption. Following the arguments put forward by Reinhart and Rogoff (2010), we assume that, on top of a higher deficit-to-GDP ratio, an increasing debt-to-GDP ratio $\left(\lambda=D / P^{H} Y\right)$ can also have a negative impact on economic activity. In the specific case of non-monetarily sovereign countries, in particular, a higher and supposedly riskier public debt stock may negatively impact on commercial banks' balance sheets due to decreasing prices of sovereign bonds. This may in turn lead commercial banks to search for higher "safety" margins on fundable projects and revise upward the mark-up rate $(\mu)$. Ceteris paribus, commercial banks will charge higher interest rates $\left(i_{H}\right)$ on loans to the private sector. Widespread turbulences on the market for sovereign bonds may materialize, together with a banking system crisis and a credit crunch on the market for loans to the private sector. Eventually, all these tightly entangled events may entail harsh effects on economic activity, and possibly drive the economy into a recession.

The debt-to-GDP ratio is commonly considered as a variable of paramount importance for assessing the long-run sustainability of public finances. Equation (26) describes the dynamics of the debt-toGDP ratio $(\lambda)$. After some mathematical passages, we get:

$$
\begin{gathered}
\left(\frac{\widehat{D}}{P^{H} Y}\right)=\hat{\lambda}=\frac{d D}{D}-\widehat{P^{H}}-\widehat{Y}=\frac{(\xi+\psi) / \beta y}{\lambda}-\widehat{P^{H}}-\hat{y}-\widehat{K}= \\
\hat{\lambda}=\frac{\xi\left(y\left(y^{e}\right) / \beta y\left(y^{e}\right)\right.}{\lambda}+\frac{\psi(\lambda) / \beta y\left(y^{e}\right)}{\lambda}-\left\{\varepsilon_{y, y^{e}} \widehat{y^{e}}+\varepsilon_{y, i_{H}} \widehat{\iota_{H}}(\lambda)-\left(1-\varepsilon_{y, q}\right) \widehat{P^{H}}\left(y^{e}\right)-g\left(y^{e}, i_{H}\right)\right\}
\end{gathered}
$$


In equation (26), $\varepsilon_{y, y^{e}}=\left(g_{y^{e}} y^{e} / y\left(y^{e}, i_{H}\right)\right)$ is the elasticity of current capacity utilization $(y)$ to the expected one $\left(y^{e}\right)$, whilst $\varepsilon_{y, i_{H}}=g_{i_{H}} i_{h} / y\left(y^{e}, i_{H}\right)$ is $y$ 's elasticity to the interest rate $\left(i_{H}\right)$. Finally, $\varepsilon_{y, q}$ is $y$ 's elasticity to the real exchange rate. For the sake of simplicity, in equation (26), we assume that both the nominal exchange rate $(e)$ and foreign prices $\left(P^{F}\right)$ do not change. Accordingly, the dynamics of the real exchange rate $(q)$ boils down to the percentage variation in the price of the domestic goods.

As to the stability properties of the debt-to-GDP ratio, it is first of all reasonable to think that when firms' expectations are more optimistic $\left(y^{e}\right)$, and hence current capacity utilization $(y)$ and investment flows $(\widehat{K})$ increase, the debt-to-GDP ratio $(\lambda)$ decreases and its dynamics are stabilized.

The effects that $\lambda$ may display on its own dynamics are trickier. Following Botta (2013), at relatively low levels of the debt-to-GDP ratio, a slightly higher value of the state variable $(\lambda)$ makes any additional public deficit less relevant in percentage terms. Accordingly, in equation (26) $\widehat{D}$ turns out to be smaller. However, at much higher values of the debt stock, some of the concerns of the supporters of EAT may materialize. On the one hand, the higher $\lambda$ is, the higher the burden of debt payments over GDP $(\psi)$ will be. ${ }^{19}$ On the other hand, $\widehat{\iota_{H}}$ may respond positively to high and increasing debt-to-GDP ratios, due to the abovementioned intertwined dynamics between $\lambda$ and the interest rate on loans to the private sector. In the end, when financial operators start to fear, rationally or not, that $\lambda$ has reached excessively high levels, destabilizing forces may set in passing through increasingly cumbersome repayment commitments, and the perverse economic effects supposedly unsafe public finances may trigger off (or imply) in the form of increasing interest rates and plummeting economic activity. ${ }^{20}$

Equations (25) and (26) jointly define an evolving economic system, in which a variety of different trajectories may emerge and define the joint dynamics of fiscal variables and economic activity. Figures 2 and 3 graphically describe (part of) such dynamics in the $\left(y^{e}-\lambda\right)$ space. According to the analysis developed above, the locus for a constant debt-to-GDP ratio $(\hat{\lambda}=0)$ may take the form of a

\footnotetext{
${ }^{19}$ This effect comes both as a natural consequence of a higher debt stock, as well as a consequence of financial operators' assessments of the financial risks characterizing highly indebted economies. Again, in particular in the case of non-monetarily sovereign countries, the accumulation of an increasing public debt stock can easily induce financial operators to raise the country factor risk $(\sigma)$, ask for higher interest rates $\left(i_{d}\right)$, and eventually make repayment conditions more stringent.

${ }^{20}$ In the analysis of equation (26), we have assumed that price dynamics and the evolution of the real exchange rate mutually compensate each other (i.e., $\varepsilon_{y, q}=1$ ). On the one hand, higher inflation reduces the real burden of the public debt stock. On the other, it may raise $\lambda$ by appreciating $q$, jeopardizing net exports, and eventually inducing a contractionary effect on current economic activity. For the sake of simplicity, we neglect to explicitly consider the direct and indirect effects $\widehat{P^{H}}$ may play on $(\hat{\lambda})$.
} 
U-shaped curve. In this sense, $\lambda_{T}$ stands for the dividing threshold of the debt-to-GDP ratio, above which financial operators believe destabilizing forces will mount. From a graphical point of view, it represents the turning point after which the upward sloping arm of the locus for $(\hat{\lambda}=0)$ emerges. In figure 2, we describe the case of self-stabilizing forces prevaling in "shaping" the dynamics of expectations; hence, the locus for $\left(\widehat{y^{e}}=0\right)$ slopes downward. In figure 3 , we portray the case for self-induced instability characterizing the dynamics of expectations. Accordingly, the locus for $\left(\widehat{y^{e}}=0\right)$ is positively sloped. In figures 2 and 3 , the vertical dashed line " $\lambda_{\max }$ " stands for the ceiling value of the debt-to-GDP ratio financial operators would agree to finance before rejecting additional treasury bond issuances and giving rise to public bankruptcy. Similarly, the horizontal dashed line represents the technology-bounded (highest) level expected and effective capacity utilization can reach.

Figure 2: Multiple equilibria in the $\left(y^{e}-\lambda\right)$ space with self-stabilizing expectations

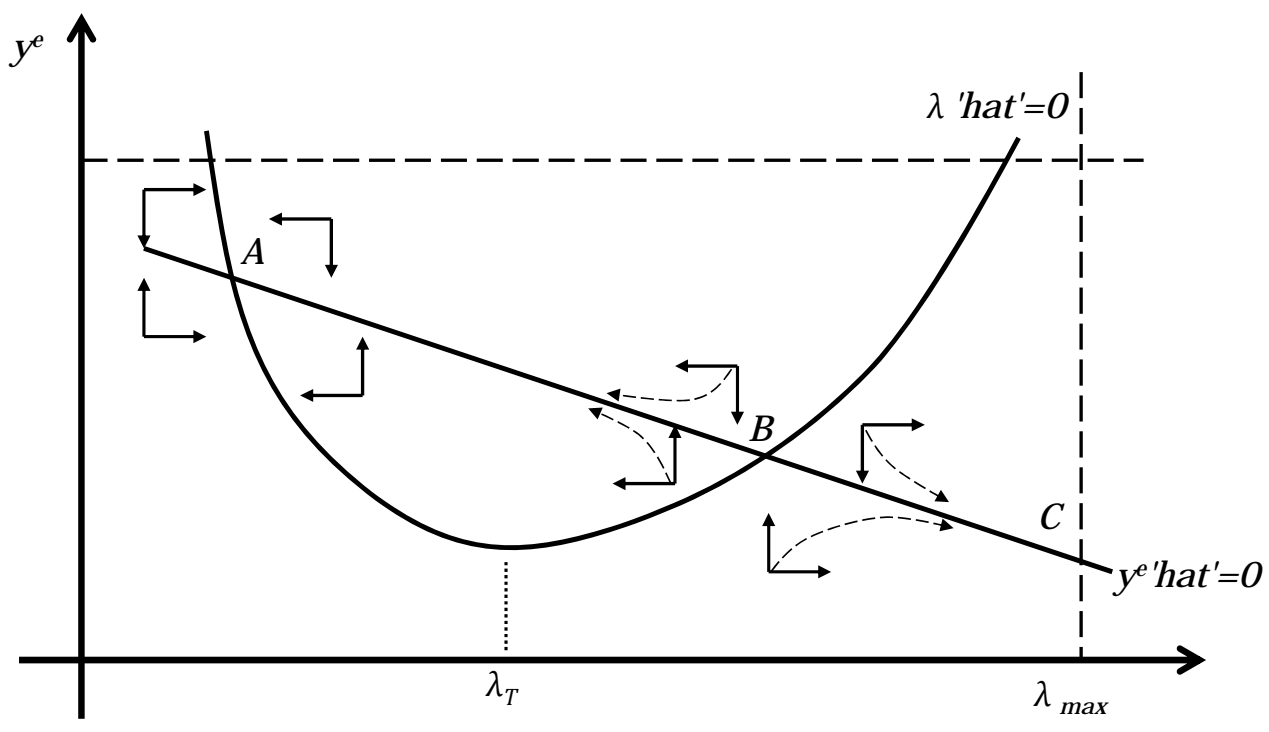


Figure 3: Multiple equilibria in the $\left(y^{e}-\lambda\right)$ space with unstable expectations

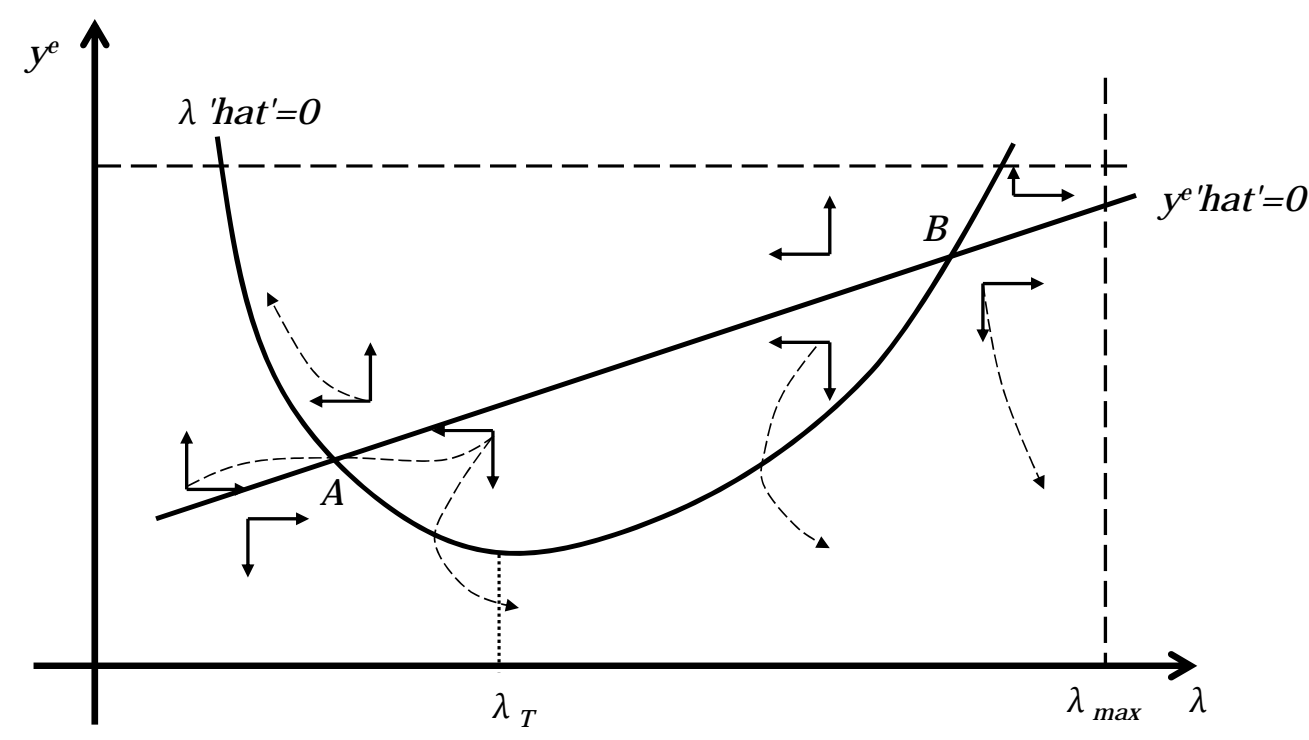

Under certain parametric conditions, the system we describe is far away from displaying the unique and stable equilibrium that usually characterizes EAT-like mainstream models populated by fully rational perfect-foresighted agents (see Bertola and Drazen 1990; Barry and Devereux 2003). In our model, path-dependence, cumulative mechanisms, and multiple equilibria dominate the scene. ${ }^{21}$ In figure 2, for instance, point $A$ represents a locally stable equilibrium featuring a relatively high level of capacity utilization and a low debt-to-GDP ratio. Nevertheless, point $B$ is a "perverse" unstable equilibrium, which combines low capacity utilization with a burdensome debt stock. On the righthand side of point $B$, worrisome cumulative mechanisms get momentum. They can move the economy towards point $C$. At point $C$, financial markets eventually repudiate sovereign bonds, and public debt default takes place, causing a collapse in economic activity.

Such destabilizing forces are even stronger in figure 3. In this case, despite a relatively low debt-toGDP level, even point $A$ shows saddle-path instability. In the absence of perfect-foresighted and optimizing agents, even a small deviation from point $A$ triggers off diverging dynamics. In an optimistic scenario, booming economic activity could go hand-in-hand with a monotonically decreasing debt stock. Alternatively, the economy may embark on a far more worrisome path, along

\footnotetext{
${ }^{21}$ The condition for multiple equilibria to exist requires $\left|(\partial \hat{\lambda} / \partial \lambda) /\left(\partial \hat{\lambda} / \partial y^{e}\right)\right|_{\hat{\lambda}=0}|>|(\partial \phi / \partial \lambda) /\left.\left(\partial \phi / \partial y^{e}\right)\right|_{\phi=0} \mid$ when $\lambda$ tends towards zero. This condition is likely to fulfil if we reasonably assume that the negative effect the EAT-like debt-to-GDP ratio $(\lambda)$ may exert on effective capacity utilization, and hence on the dynamics of expectations, is close to zero and negligible at low levels of the debt-to-GDP ratio itself.
} 
which collapsing expectations and economic activity mutually feedback into a mounting and unsustainable debt burden, eventually leading to a bankruptcy of the public sector.

\subsection{Short-run Costs with Long-run Benefits? The Intrinsic Long-run Inconsistency of EAT}

Given the above scenarios, might well-designed austerity packages be a bitter medicine against fiscal indiscipline in the short run, but revitalizing for the economy in the long run?

Let us assume that the government implements a drastic and permanent cut in public transfers and/or social service provisions, i.e., $\rho$ and $\widehat{\omega}$ decrease in equation (16). As some recent contributions in the EAT vein themselves admit, let us assume these measures curtail economic activity in the short-run. If so, in figure 4 such a contractionary fiscal policy shock shifts the isocline for $(\hat{\lambda}=0)$ upward. At the same time, the isocline for $\left(\widehat{y^{e}}=0\right)$ moves downward. In figure 4, it turns out to be clear that the long-run consequences of an austerity-led short-term recession are radically at odds with the EAT-expected results. Should the economy be initially located at equilibrium point $A$, it will eventually end up at equilibrium $A_{2}$, featuring both depressed expected and effective economic activity (at least with respect to that associated with the initial equilibrium), and an increased debt burden. Even more worrisome, should the economy be located in equilibrium $B$, an endless crisis and a mounting unsustainable debt stock will eventually bring the economy towards an inevitable default (point $B_{2}$ in figure 4).

Such undesirable long-run outcomes of short-term austerity-led contractions would arise even more easily in the radically unstable macroeconomic environment described in figure 3 . In such a scenario, long-run instability would emerge even with an economy originally located at the apparently safe low-debt equilibrium point, $A$. Due to economic actors' expectations overreacting to fiscal policy shocks, even a slight upward shift in the isoclines for constant values of $\lambda$ and $y^{e}$ (see figure 5) will eventually induce a permanent contraction in economic activity and an unsustainable public-debt-to-GDP ratio. 
Figure 4: Long-run outcomes of austerity-led short-run recessions in a stable dynamic scenario

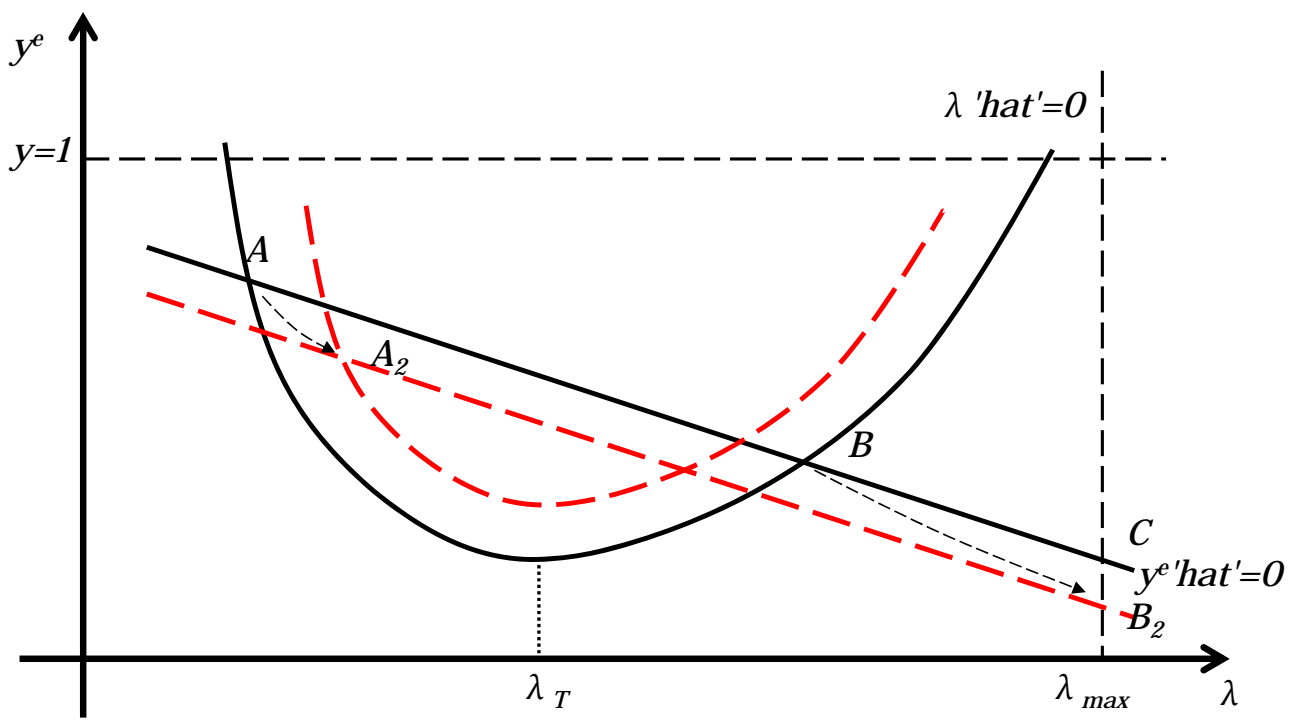

Figure 5: Long-run outcomes of austerity-led short-run recession in an unstable dynamic scenario

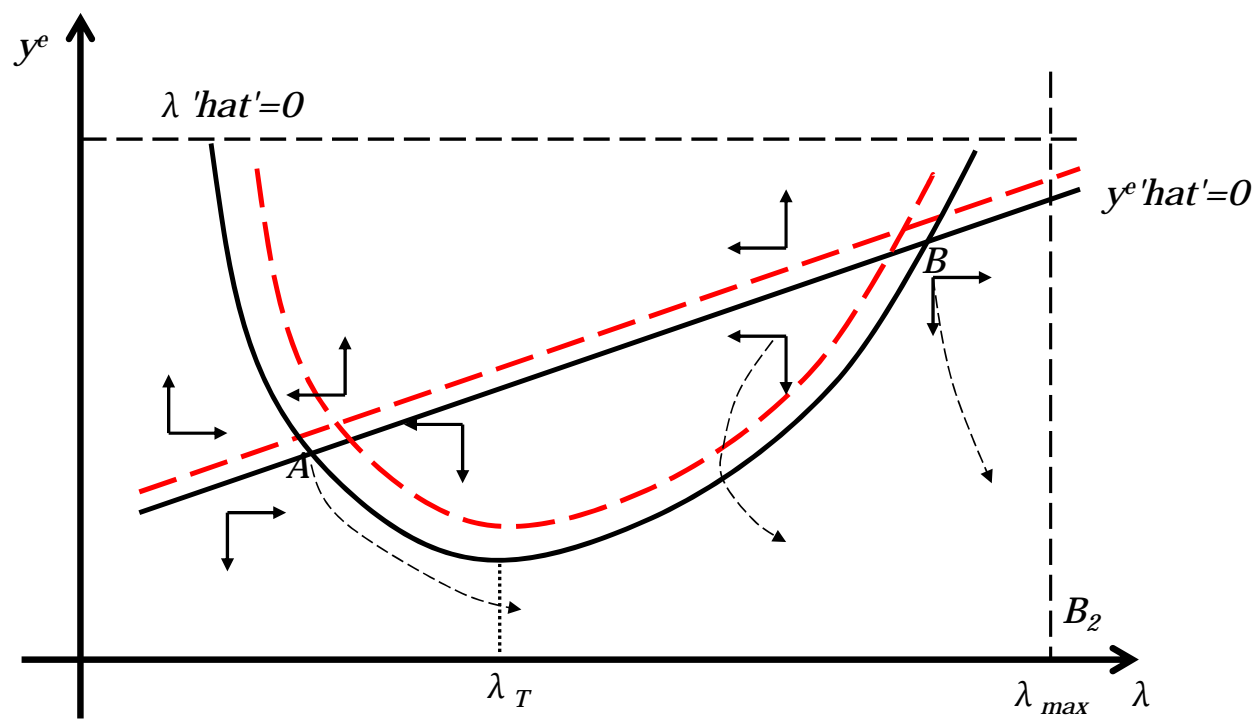

More in general, the economy we describe, or at least some relevant economic variables, may display explosive cumulative dynamics. This is the case of the debt-to-GDP ratio when government bonds are issued by non-monetarily sovereign countries; public debt sustainability is in the hands of financial market operators, and $\lambda$ eventually exceeds the stability thresholds financial operators have adopted as a shared but fragile convention. These non-linear, possibly cumulative dynamics are the source of path-dependence and multiple trajectories. A common aspect of these trajectories 
is that short-run austerity-led costs cause even larger pains (and no benefits) in the long run. In the context of unstable expectation dynamics and/or highly indebted economies, they risk making the macroeconomy more vulnerable and unstable, rather than safer and more solid. This is why "a radical solution for high debt is [may be] to do nothing at all — [and] just live with it" (Ostry and Gosh 2015), at least when we come to consider tough fiscal retrenchments as an option for tackling it. The other way around, short-run costs and long-run benefits of austerity measures are mutually inconsistent. Even in a theoretical framework that takes on board some crucial EAT assumptions, austerity must be expansionary in the short run in order to pay off in the long run. Unfortunately, we have seen at length how the former events (i.e., short-run austerity-led expansions) are very unlikely to happen.

\subsection{The Case for Endogenous Monetary Institutions}

In our model, country-specific institutions contribute to determining the short- and long-run outcome of fiscal shocks. In more detail, the specific rules guiding central bank flexibility in purchasing government bonds and taking action against financial distress crucially modify how austerity may affect economic activity, the public deficit, and the public debt.

In the short run, the degree of monetary sovereignty of an economy contributes to defining the active channel through which fiscal consolidation might deliver expansionary outcomes. In monetarily sovereign countries, the central bank can easily buy government bonds in order to backstop any extraordinary fiscal effort against economic and financial crises. This is why it is a common belief that "[s]overeigns do not default" (Kregel 2012: 3). This is also why bonds issued by monetarily sovereign countries are perceived as risk-free assets, and safe shelter where financial operators store funds in times mounting uncertainty. According to these facts, the "financial channel" through which austerity might hypothetically boost growth is not at work in monetarily sovereign economies. Such a channel may be operative in the non-monetarily sovereign eurozone member states; however, its effectiveness is contingent upon the highly debatable capacity of austerity measures to prompt expansions and squeeze public deficits (and debts) from the very onset.

The degree of monetary sovereignty can fundamentally alter the long-run stability of the economy. In monetarily sovereign countries, the domestic central bank can promptly neutralize the negative effects that an increasing debt-to-GDP ratio may display on financial and credit markets. In terms of our model, this implies eliminating, or at least taming, the explosive consequences that debt stock that is too high may induce on its own dynamics (via $\psi$ and $\widehat{\iota_{H}}$ ) once it has overcome the stability 
threshold $\lambda_{T}$. Graphically (see figure 2), this amounts to removing the upward sloping part of the locus for $(\hat{\lambda}=0)$, or at least making it emerge at a far higher value of the debt-to-GDP ratio, and with a much flatter slope. In sum, full monetary sovereignty can significantly expand the safe area (say the stability zone surrounding point $A$ in figure 2) financial operators may bear in mind, and impede destabilizing mechanisms from originating. By the same token, the lack of monetary sovereignty constitutes a fundamental source of financial fragility, as the eurozone experienced in the immediate aftermath of the worldwide financial crisis.

In this model, we presented such an institutional dichotomy as exogenously given, and captured by the binary time-invariant parameter $(\Omega)$. Nonetheless, the events taking place in the eurozone since 2012 demonstrate that institutions, monetary institutions among them, can also co-evolve through time together with "pure" economic variables. The 2007-08 financial crisis initially emerged as an external shock to euro countries. Due to the peculiar features or, better, the shortcomings of eurozone institutional building, a private debt crisis evolved into an even worse sovereign debt crisis. The inability of the euro system to deal with this problem, and the increasing risk of a eurozone suicide, eventually induced the ECB to pursue a gradual and partial, yet important drift towards an embryonic (and path-dependent) form of monetary sovereignty. ${ }^{22}$ In the end, the "whatever it takes" statement by Mario Draghi, and the launch of the outright monetary transactions (OMT) program, may constitute good examples of endogenous structural (say institutional) changes (Lordon 1997) inspired by the intrinsic dynamics of the system, and by the very same economic issues they aim to tackle.

The effects of such a change are well known. Previous hikes in the interest rates of sovereign bonds issued by peripheral eurozone countries have literally disappeared. Since mid-2012, interest rates on public debt have constantly decreased, now reaching historically low levels. Financial operators have stopped obsessively scrutinizing the solidity of public finances of peripheral countries. In terms of our model, figure 6 portrays the stabilizing forces sparked in the eurozone by the so-called "Draghi put."

\footnotetext{
${ }^{22}$ Path dependency here emerges from the perhaps unusual and original institutional arrangements the euro system adopted in 2012 in order to definitively snap-off financial turbulences, given the existing (legal and political) constraints to the goals the ECB should pursue, the actions it could take, and the lack of a centralized eurozone fiscal authority.
} 
Figure 6: Stabilizing macroeconomic effects of monetary sovereignty

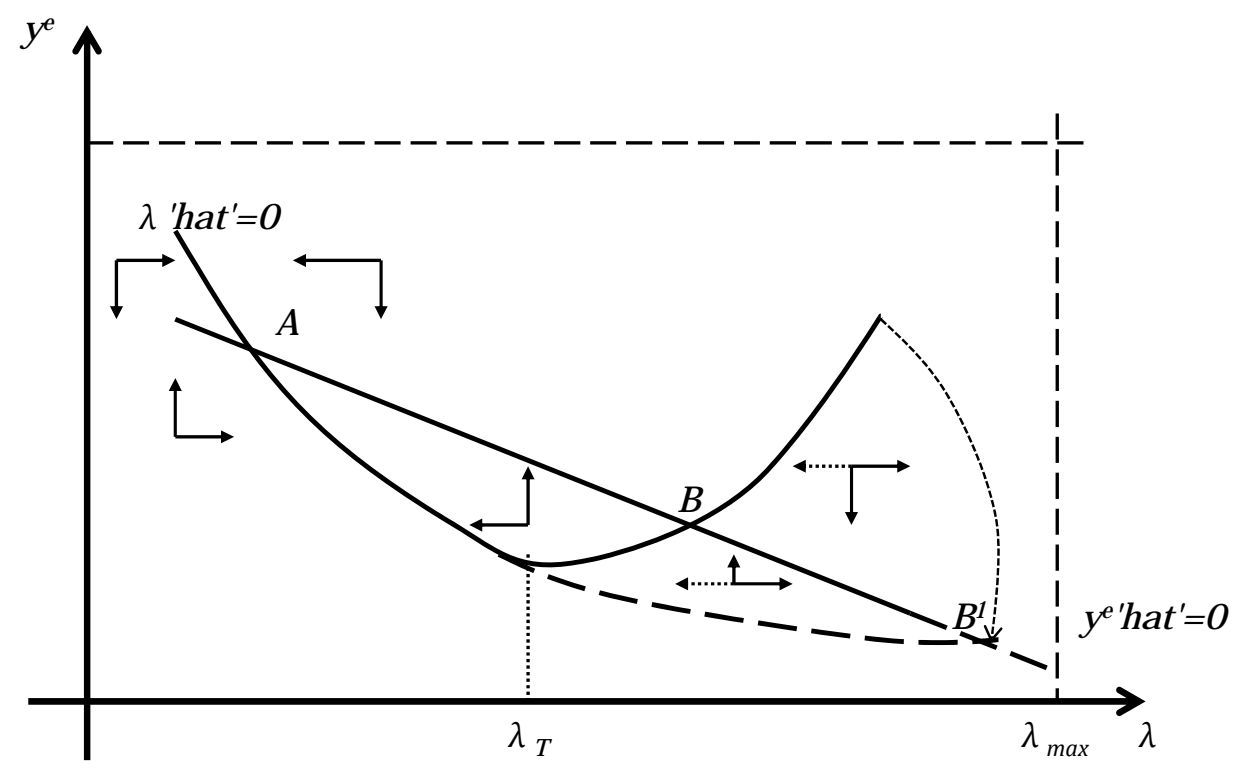

Let's assume that the worldwide "Great Recession" and the rescue packages of domestic financial institutions cause public deficits and public debts to suddenly rise. Let us also assume that debt-toGDP ratios overcome the stability threshold $\left(\lambda_{T}\right)$, which financial operators fix at relatively low levels in the specific case of (non-monetarily sovereign) eurozone countries. In the absence of any significant change, financial turbulences would mount and peripheral eurozone countries would find themselves stuck on the verge of bankruptcy (as effectively happened). The extraordinary measures taken by the ECB board at the height of the crisis represent the endogenous response of the system to such an apparently inevitable end. In figure 6, the upward-sloping arm of the locus for $(\hat{\lambda}=0)$ moves downward and changes slope. The isocline for constant values of the debt-to-GDP ratio $(\lambda)$ gets transformed into a prevalently downward-sloping locus. Point $\mathrm{B}$ shifts to point $B^{l}$; the destabilizing forces on the right of point $B$ are inverted into stabilizing ones (see newly emerging dotted arrows). The economies that were desperately fighting against a seemingly unavoidable default can now rejoin stability, and (perhaps gradually) converge back to point A.

\section{CONCLUSIONS}

An increasing body of literature admits that front-loaded fiscal retrenchments can likely cause an economic recession and an increasing debt-to-GDP ratio (Gros 2012; Ali Abbas et al. 2013; Warmedinger, Checherita-Westphal, and Hernandez de Cos 2015) in the short run. The short-run 
version of our models shows this concern to be well grounded. Nonetheless, the literature mentioned above describes recession and rising debt-to-GDP ratios as the necessary costs in the short run in order to reap much higher benefits in the long run. In this paper, we show how this proposition is theoretically inconsistent. In order to pay off in the long run, austerity must be expansionary and debt reducing from the very onset. Unfortunately, economists and policymakers alike are increasingly skeptical this will ever materialize.

In light of these findings, the right policy recipe against the sovereign debt crisis, and the right timing for implementing it, look radically different from what has effectively been done so far in the eurozone. In the case of highly indebted non-monetarily sovereign economies like Greece, in the absence of any radical institutional change, macroeconomic stability and growth can be primarily achieved through significant debt relief. Instead of waiting, as the ECB did before it intervened in July of 2012, monetary institutions should take immediate and decisive action to strike financial speculation and to neutralize the mounting debt crisis. This would give national governments more space for gradually maneuvering to less painful reform of their economies in a more stable environment. Only subsequently could some mild austerity measures be considered in those (few) countries dealing with some problems of fiscal profligacy.

Following Eichengreen and Panizza (2014), adjustment programs that are too ambitious and prolonged are hardly implementable. They also fail to recognize that significant reductions in the debt burden have historically occurred during periods of high growth, rather than in periods of recession or anemic growth. If growth is the main way out of the crisis, and one does not want to openly consider expansionary fiscal policies, attention should at least focus on public support for policies related to industry, innovation, and investment. Public investment banks (in the case of the eurozone, the European Investment Bank), if not governments directly, may turn out to be decisive actors to eventually prompt a sustained and sustainable recovery. 


\section{REFERENCES}

Alesina, A. 2010. "Fiscal adjustments: lessons from recent history." Paper prepared for the EU Ecofin meeting in Madrid, April 15.

Alesina, A., and R. Perotti. 1995. "Fiscal Expansions and Fiscal Adjustments in OECD Countries." NBER Working Paper no. 5214. Cambridge, MA: National Bureau of Economic Research.

Alesina, A., and R. Perotti. 1997. "Fiscal Adjustments in OECD Countries: Composition and Macroeconomic Effects." IMF Staff Papers 44(2): 210-48.

Alesina, A., and S. Ardagna. 2010. "Large Changes in Fiscal Policy: Tax versus Spending.” In J.R. Brown (ed.) Tax Policy and the Economy. Chicago: University of Chicago Press.

Alesina, A., and S. Ardagna. 2012. "The Design of Fiscal Adjustments.” NBER Working Paper no. 8423. Cambridge, MA: National Bureau of Economic Research.

Alesina, A., C. Favero, and F. Giavazzi. 2015. "The Output Effects of Fiscal Consolidation Plans." Journal of International Economics 96(supplement 1): S19 - S42.

Ali Abbas, A., B. Akitoby, J. Andritzki, H. Berger, T. Komatsuzaki, and J. Taylor. 2013. "Dealing with High Debt in an Era of Low Growth.” IMF Staff Discussion Note 13/07. Washington, DC: International Monetary Fund.

Auerbach, A., and Y. Gorodnichenko. 2012. "Measuring the Output Responses to Fiscal Policy." American Economic Journal: Economic Policy 4(2): 1-27.

Baker, D., and D. Rosnick. 2014. "Stimulus and fiscal consolidation: The evidence and implications.” IMK Working Paper no.135. Düsseldorf: Hans Böckler Foundation.

Barry, F., and M.B. Devereux. 2003. "Expansionary Fiscal Contraction: A Theoretical Explanation." Journal of Macroeconomics 25(1): 1-23.

Batini, N., G. Callegari, and G. Melina. 2012. "Successful Austerity in the United States, Europe, and Japan.” IMF Working Paper no. 190. Washington, DC: International Monetary Fund.

Baum, A., M. Poplawski-Ribeiro, and A. Weber. 2012. "Fiscal Multipliers and the State of the Economy.” IMF Working Paper no. 286. Washington, DC: International Monetary Fund.

Bertola, G., and A. Drazen. 1990. "Trigger Points and Budget Cuts: Explaining the Effects of Fiscal Austerity." NBER Working Paper no. 3844. Cambridge, MA: National Bureau of Economic Research.

Botta, A. 2013. "Fiscal Policy, Eurobonds, and Economic Recovery: Heterodox Policy Recipes Against Financial Instability and Sovereign Debt Crisis" Journal of post-Keynesian Economics 35(3): 417-41.

Boyer, R. 2012. "The four fallacies of contemporary austerity policies: the lost Keynesian legacy." Cambridge Journal of Economics 36(1): 283-312.

De Grauwe, P. 2011. “Managing a fragile eurozone.” CESifo Forum 12(2): 40-45. 
De Grauwe, P., and Y. Ji. 2013. "Self-fulfilling Crises in the Eurozone: An Empirical Test." Journal of International Money and Finance 34(April): 15-36.

Dosi, G., M. Napoletano, A. Roventini, and T. Treibich. 2015. "The Short- and Long-run Damages of Fiscal Austerity: Keynes beyond Schumpeter.” In J.E. Stiglitz and M. Guzman (eds.) Contemporary Issues in Macroeconomics. Lessons from the Crisis and Beyond. Basingstoke and New York: Palgrave MacMillan.

Dosi, G., and M. Egidi. 1991. "Substantive and Procedural Uncertainty_An exploration of Economic Behavior in Changing Environments." Journal of Evolutionary Economics 1(2): $145-68$.

Eichengreen, B., and U. Panizza. 2014. "A Surplus of Ambition: Can Europe Rely on Large Primary Surpluses to Solve its Debt Problem?” NBER Working Paper no. 20316. Cambridge, MA: National Bureau of Economic Research.

Foresti, P., and U. Marani. 2014. "Expansionary fiscal consolidations: Theoretical underpinnings and their implications for the eurozone." Contributions to Political Economy 33(1): 19-33.

Giavazzi, F., and M. Pagano. 1990. "Can Severe Fiscal Contractions Be Expansionary? Tales of Two Small European Countries.” NBER Macroeconomic Annual 5: 75-122.

Giavazzi, F., and M. Pagano. 1996. "Non-Keynesian Effects of Fiscal Policy Changes: International Evidence and the Swedish Experience." Swedish Economic Policy Review 39(3): 635-57.

Gros, D. 2012. "Can Austerity be Self-defeating? Credible Austerity Plans are Required." Intereconomics 47(3): 175-77.

Guajardo J., D. Leigh, and A. Pescatori. 2011. "Expansionary Austerity: New Empirical Evidence.” IMF Working Paper no. 158: Washington, DC: International Monetary Fund.

Kregel J. 2012. "Six Lessons from the Euro Crisis.” Levy Economics Institute Policy Note 2012/10. Annandale-on-Hudson, NY: Levy Economics Institute of Bard College.

Lordon, F. 1997. "Endogenous Structural Change and Crisis in a Multiple Time-scales Growth Model." Journal of Evolutionary Economics 7(1): 1-21.

Mehrling, P. 2011. The New Lombard Street. How the Fed Became a Dealer of Last Resort. Princeton, NJ: Princeton University Press.

Ostry, J.D., and A.R. Ghosh. 2015. "When is Repaying Public Debt Not of the Essence?" Blog post, IMF Direct. Available at: https://blog-imfdirect.imf.org/2015/06/02/when-is-repayingpublic-debt-not-of-the-essence/.

Palley, T. 2010. "The Simple Macroeconomics of Fiscal Austerity, Public Sector Debt and Deflation.” IMK Working Paper no. 8/2010. Düsseldorf: Hans Böckler Foundation.

Perotti, R. 2012. “The 'Austerity Myth': Gain without Pain?” In A. Alesina and F. Giavazzi (eds.) Fiscal Policy after the Financial Crisis. Chicago: University of Chicago Press.

Qazizada, W., and E. Stockhammer. 2015. "Government spending multipliers in contractions and expansions.” International Review of Applied Economics 29(2): 238-58. 
Radzicki, M.J., and J.D. Sterman. 1994. "Evolutionary Economics and System Dynamics.” In R.W. England (ed.) Evolutionary Concepts in Contemporary Economics. Ann Arbor, MI: The University of Michigan Press.

Reinhart, C.M., and K.S. Rogoff. 2010. "Growth in a Time of Debt." American Economic Review Paper and Proceedings 100(May): 573-78.

Sutherland, A. 1997. "Fiscal Crises and Aggregate Demand: Can High Public Debt Reverse the Effect of Fiscal Policy?" Journal of Public Economics 65(2): 147-62.

Taylor, L. 1991. Income Distribution, Inflation and Growth: Lectures on Structuralist Macroeconomic Theory. Cambridge, MA: MIT Press.

Taylor, L. 2004. Reconstructing Macroeconomics. Cambridge, MA: Harvard University Press.

Taylor, L. 2012. “Growth, Cycles, Asset Prices and Finance.” Metroeconomica 63(1): 40-63.

Warmedinger, T., C. Checherita-Westphal, and P. Hernandez de Cos. 2015. "Fiscal Multipliers and Beyond.” ECB Occasional Paper Series no.162/June 2015. Frankfurt: European Central Bank. 